\title{
Recreation and sports in Minneapolis Indoor and outdoor escapes for everyone
}

It is April, in Minnesota, we eat outdoors because

It is warm, in the upper forties, it's warm enough for us.

It is April, in Minnesota, tonight we'll eat outside. It is cold but we don't say so, it's Minnesota pride.

Song lyrics from Prairie Home Companion show. Saturday, April 10, 2004.

B $y$ the time the 2005 ACRL National Conference arrives, spring in Minneapolis will not quite be at the point of apple blossoms, sailing, and peak spring bird migration. Even so, there are a great number of recreational activities and sporting events waiting to be tried during your visit to the Land of 10,000 Lakes.

So, what is the Minnesota weather like in April? Historically, on April 7-10, the days of the ACRL conference, the average temperature is around 43 degrees Fahrenheit. Snowfall is possible, but there has been no snowfall during these dates in the past five years. Short of promises for what the 2005 ACRL National Conference days will hold, this is definitely weather in which to get out, explore, and have fun!

\section{Indoor/Outdoor Recreation Chain of Lakes and Parks}

Residents of the Twin Cities are proud of their fabulous park system and the multitude of lakes within the cities' limits-there are more than 20! Near the downtown Min- neapolis area, there is a chain of five beautiful lakes that have paths for walking, jogging, biking, and in-line skating.

In particular, the Lake Calhoun and Lake Harriet section of the chain is very popular. It's just minutes from downtown in a hip, popular area known as "Uptown" Minneapolis. Take a 3.1-mile trip around Lake Calhoun, a favorite place for windsurfers, canoeists, kayakers, and sailors in the summer, and for ice fishing during the winter. Next, follow the path to Lake Harriet and take a 2.8-mile trip around this lovely lake to view some of the city's most palatial homes.

\section{Minneapolis Riverfront}

If you prefer to stay downtown, explore the Minneapolis Riverfront's maze of beautiful parks and trails. Try the St. Anthony Falls Heritage Trail, a self-guided tour of the St. Anthony Falls Historic District. For hundreds of years this area has been an important and pivotal place as it evolved from a Dakota Indian spiritual ground to the center of the milling industry.

Follow the 1.8-mile year-round historic walking trail along the Mississippi River via Nicollet Island and the Hennepin Avenue and Stone Arch bridges. Watch for kiosks, markers, and signs along the trail to learn more about the historical significance of this area.

Angi Faiks is associate library director and collection management team leader at Macalester College, email:faiks@Macalester.edu, and Philip Herold is head of the Forestry Library at University of Minnesota, e-mail: herol008@umn.edu

๑) 2005 Angi Faiks and Philip Herold 


\section{Links to attractions \\ Bryant-Lake Bowl \\ www.bryantlakebowl.com \\ Chain of Lakes \\ www.minneapolisparks.org/grandrounds/ \\ dist_CL.htm}

The Depot Ice Skating Rink

www.thedepotminneapolis.com/rink.htm

Minneapolis Riverfront

WwW.minneapolis-riverfront.com

Minnesota Landscape Arboretum

www.arboretum.umn.edu

Minnesota Timberwolves Basketball

www.nba.com/timberwolves/index.html

Minnesota Twins Baseball

minnesota.twins.mlb.com

\section{Minnesota Wild Hockey}

www.wild.com

\section{Indoor Ice Skating at the Depot Rink}

If you feel like taking part in one of Minnesotans favorite pastimes, head to the Depot Rink for indoor ice skating. The Old Milwaukee Road Depot, built in 1899, is now a one-of-a-kind, climate-controlled indoor ice skating rink. The restored pavilion has floorto-ceiling glass windows, providing a gorgeous view of the city during the day and the downtown skyline at night. The Depot Ice Skating Rink closes for the season on April 8th, so if you wish to go, make sure to get there when you first arrive for ACRL.

\section{Bryant-Lake Bowl}

There is no place in town quite like Bryant-Lake Bowl in the Minneapolis Uptown neighborhood. For those of you whose idea of exercise includes worn bowling shoes and a great microbrew, this is the place for you! Putting a new and decisively cool "spin" on the neighborhood bowling alley, this establishment also features a restaurant with an eclectic menu, as well as a bar, coffee- house, and live music and community theater events. So, come with your colleagues to play (and have) a few rounds!

\section{Como Park Zoo and Conservatory}

A quick trip by bus or car to St. Paul will take you to the Como Park Zoo and Marjorie McNeely Conservatory, the largest glassdomed garden in the region. Come see the lovely gardens housed under a half acre of glass. The Conservatory is open year-round and the entrance donation is $\$ 1$. The Como Park Zoo next door is also open year-round, and both parking and admission are free.

\section{Minnesota Landscape Arboretum}

If you have the means to travel while visiting, definitely consider the Minnesota Landscape Arboretum, which is about 25 miles from the Twin Cities. Minnesota's largest public garden on 1,000 acres is open yearround. Enjoy miles of hiking trails and, in the winter, cross-country ski trails as you weave through woodlands, native prairie, and natural marshes. The Arboretum offers a restaurant, gift shop, conservatory, and wonderful library.

\section{Sporting Events}

Three of Minnesota's professional sports teams are hosting home games during the ACRL National Conference. If you love baseball, the Minnesota Twins will confront the rival Chicago White Sox on April 8th, 9th, and 10th at the Hubert H. Humphrey Metrodome in downtown Minneapolis. No matter the weather, the fiberglass-covered Metrodome ensures that the games will go on. Trivia buffs will be interested in knowing that this is the only air-supported dome in the major leagues. Revolving doors at the entrances prevent the release of the air that keeps the dome upright. And another piece of triviathe Metrodome roof collapsed on April 14, 1983 , from the weight of heavy snow!

If the National Hockey League opens the doors to end the current lockout and the league does play hockey this year, then the

(Continued on page 42) 
Leslie Madden, reference librarian, Georgia Institute of Technology.

\section{Western European Studies Section}

Vice-chair/Chair-elect: Sebastian Hierl, bibliographer for English and romance Literatures, University of Chicago; Bryan Skib, coordinator of graduate library collections, University of Michigan.

Secretary: Laura Dale Bischof, librarian for German and Western European history, University of Minnesota; David Lincove, history, political science and philosophy librarian, Ohio State University.

Member-at-Large: Heather Ward, humanities librarian, University of Oregon; Sarah
Wenzel, reference coordinator, Humanities Library, Massachusetts Institute of Technology.

\section{Women's Studies Section}

Vice-chair/Chair-elect: Kelly Barrick Hovendick, interim head, reference, Syracuse University Library.

Secretary: Cynthia Johnson, director of reader services, Pratt Institute; Susan Kane, reference librarian/women studies librarian, University of Washington.

Member-at-Large: Pamela Mann, Mexican American/Latino studies librarian, University of Texas; Diane Gwamanda, head of access services, University of Houston. n
("Recreation..." continued from page 12)

Minnesota Wild are scheduled to play the Detroit Redwings on April 10th at the Excel Energy Center in downtown St. Paul.

And the Minnesota Timberwolves, led by last year's NBA Most Valuable Player, Kevin Garnett, play the Denver Nuggets in basketball at the Target Center in downtown
Minneapolis on April 8th.

Whether you are interested in getting some exercise, taking a stroll down the river, or taking in world-class sporting events, you will find many attractions to keep you fit, relaxed, and entertained. Enjoy your time in the fabulous Twin Cities! $\approx$
("RFID" continued from page 16)

10. Consumers Against Supermarket Privacy Invasion and Numbering, et al., RFID Position Statement of Consumer Privacy and Civil Liberties Organizations, November 20, 2003, www.privacyrights.org/ar/RFIDposition.htm (accessed 21 June 2004).

11. Electronic Frontier Foundation, EFF Comments to San Francisco Public Libraries, www.eff.org/Privacy/Surveillance/ RFID/20031002_sfpl_comments.php (accessed 10 February 2004).

12. California Senate, Energy, Utilities and Communications Committee, Subcommittee on New Technologies, Informational Hearing: RFID Technology and Pervasive Computing (Sacramento, 2003), www.sen. ca.gov/ftp/SEN/COMMITTEE/STANDING/
ENERGY/_home/08-18-03agenda.htm (accessed 07 June 2004).

13. Beth Givens, "RFID implementation in libraries: some recommendations for best practices" (paper presented at the Midwinter Meeting of the American Library Association, San Diego, January 2004), www.privacyrights. org/ar/RFID-ALA.htm (accessed 15 June 2004).

14. Berkeley Public Library, Best Practices for RFID Technology, berkeleypubliclibrary. org/BESTPRAC.pdf (accessed 15 June 2004).

15. Ann Cavoukian, Guidelines for Using RFID Tags in Ontario Public Libraries, Toronto, Ontario: Information and Privacy Commissioner/Ontario. (June 2004), www. ipc.on.ca/docs/rfid-lib.pdf (accessed 21 June 2004). $n$ 